\title{
A study on fungicides potential and incidence of sheath rot of rice caused by Sarocladium oryzae (Sawada)
}

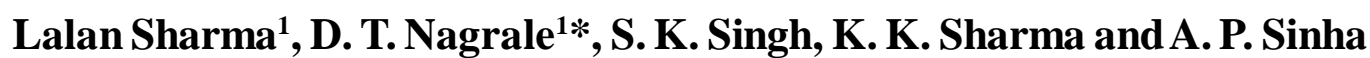 \\ ${ }^{1}$ National Bureau of Agriculturally Important Microorganisms, Kusmaur, Maunath Bhanjan-275101(U.P.), INDIA \\ Department of Plant Pathology, College of Agriculture, G. B. Pant University of Agriculture and Technology, Pantnagar- \\ 263145 (UK), INDIA \\ *Corresponding author. E-mail: drsharmanbaim@ rediffmail.com \\ Received: D ecember 21, 2012; Revised received:J anuary 20, 2013; Accepted:J anuary 27, 2013
}

Abstract: Sheath rot, Sarocdadium oryzae (Sawada) Gams. and Hawksw., has recently become a serious disease of rice when climatic conditions are unfavorable during flag sheath development. In this study systemic and nonsystemic fungicides were tested against S. oryzae. Maximum inhibition of radial growth $(76.53 \%)$ was recorded at $10.0 \mathrm{ppm}$ of tebuconazole fungicides. In non-systemic fungicides, maximum inhibition of radial growth $(78.86 \%)$ was recorded at 200.0ppm. Comparative efficacy of fungicides on sheath rot was tested during Kharif 2008-2009. Foliar spray of tebuconazole was found superior overall other treatments giving reduction in disease severity (59.01-64.33\%), which was followed by followed by carbendazim (48.70-55.28\%), and also increased grain yield per plant (45.06-65.84\%), grain yield per plot (45.57-65.85\%), 1000-grains weight (10.80-52.58\%) and reduction in chaffiness (48.07-53.80\%). Among non-systemic fungicides chorothalonil was found best in managing sheath rot, giving reduction in disease severity $(35.68-38.85 \%)$, and also increased grain yield per plant $(24.78-44.74 \%)$, grain yield per plot (24.52-44.57\%), 1000-grains weight (4.25-35.47\%) and reduction in chaffiness (15.74-45.96\%) as compared to check. Another field experiment was conducted during Kharif 2009-10 to observe sheath rot incidence on rice cultivars in Tarai region. The incidence was recorded in thirty three varieties; only varieties (Type- 3 and Basmati-370) were recorded as free from disease symptoms.

Keywords: Fungicides, Germplasm, S arocladium oryzae, Sheath rot

\section{INTRODUCTION}

Rice, the staple food of nearly half of the humanity is mainly grown and consumed in Asian countries such as India, China, Japan, Indonesia, Thailand, Pakistan, Bangladesh, North and South Koreas, Myanmar, Philippines, Sri Lanka etc. It is constantly subjected to several fungal, bacterial, viral and nematode diseases. Sheath rot, caused by Sarocdadium oryzae (Sawada) Gams. and Hawksw. has gained the status of a major disease of rice and yield loss varies from 9.6 to $85 \%$. The fungus is detected frequently during routine seed health testing and causes empty grain production (Kulwanth and Mathur, 1992) and glume discolouration (Sachan and Agarwal,1995) and also seed diclouration (Reddy et al., 2000). It also causes poor grain filling and reduction in seed germination (Vidhyasekaran et al., 1984). Seeds from infected panicles became discoloured and sterile (Mew and Gonzales, 2002). Lack of knowledge on the genetic variability and virulence pattern of the pathogen, it is difficult to develop sheath rot resistance varieties. Fungicides are playing pivotal role in reducing crop losses. Therefore, in this study, the work was done to identify potential fungicides that may be cost effective to manage sheath rot of rice caused by $\mathrm{S}$. oryzae and also to screen elite germplasm for the possibility of developing resistant varieties for the management of sheath rot of rice.

\section{MATERIALS AND METHODS}

The present studies were carried out at Rice Pathology laboratory and Glasshouse in the Department of Plant Pathology. However, field experiments were conducted consecutively for two Kharif crop seasons 2008 and 2009 at Crop Research Center, G.B. Pant University of Agriculture and Technology, Pantnagar, U.S. Nagar (Uttrakhand). Topographically, Pantnagar is located at $29^{\circ} \mathrm{N}$ latitude, $79.3^{\circ} \mathrm{E}$ longitude and at an altitude of 243.84 meter above the mean sea level in the humid and subtropical regions of North West Plain Zone at the foothills of Shivalik range of Himalayas. The average relative humidity was highest (70-90\%) in July-August and December-January and lowest (35-40\%) in April-May. The procedures adopted in the experimentation are as follows:

Collections of sheath rot diseased samples: Rice growing areas in tarai region and adjoining areas of Uttarakhand were surveyed during the crop season. Diseased plants showing sheath rot symptom were collected from 
different locations. The samples were kept in clean polythene bag and each sample was marked clearly to show details of the location and variety. The samples were brought to the laboratory for microscopic examination, isolation, purification and pathogenicity test In vitro evaluation of fungicides: Experiments on the screening of fungicides (systemic and non-systemic) were tested against different isolates of $\mathrm{S}$. oryzae, under laboratory conditions by using Poisoned Food Technique (Grover and Moore, 1966). Systemic fungicides (hexaconazole, carbendazim, tebuconazole and propeconazole) were tested at 2.5, 5.0, 10.0 and 20.0ppm and non-systemic (mancozeb, chlorothalonil, copper hydroxide and sulphur) at 25.0, 50.0, 100.0 and 200.0ppm concentrations added to double strength sterilized Kirchooff's medium. Stock solution of each treatment (fungicides) was prepared by dissolving weighted quantity in a measured value of sterilized distilled water. The amount of stock solution to be added to Kirchooff's medium was calculated by following formula:

$\mathrm{C}_{1} \mathrm{~V}_{1}=\mathrm{C}_{2} \mathrm{~V}_{2}$

Where, $\mathrm{C}_{1}=$ Concentration of stock solution $(\mu \mathrm{g} / \mathrm{ml}), \mathrm{C}_{2}$ $=$ Desired concentration $(\mu \mathrm{g} / \mathrm{ml}), \mathrm{V}_{1}=$ Volume $(\mathrm{ml})$ of the stock solution to be added, $\mathrm{V}_{2}=$ Measured volume $(\mathrm{ml})$ of the Kirchooff's medium

Kirchooff's medium medium poisoned with various concentrations of different fungicides was poured @ 20 $\mathrm{ml}$ per Petri plates aseptically. For each concentration of fungicides, three replications were maintained. After solidification of medium, each plate was centrally inoculated with $5 \mathrm{~mm}$ disc cut from the edge of 10 days old culture of different isolates of S. oryzae using sterilized sharp cork borer. Petri plates without fungicide concentration inoculated with $\mathrm{S}$. oryzae isolate were served as check. All inoculated Petri plate was incubated at $26 \pm 1^{\circ} \mathrm{C}$. Radial growth was measured 12 days after inoculation with the help of measuring scale. Percent radial growth inhibition over control was calculated by applying the following formula (Mc kinney, 1923).

$$
\mathrm{I}=\frac{\mathrm{C}-\mathrm{T}}{\mathrm{C}} \times 100
$$

Where, $\mathrm{I}=$ Percent inhibition; $\mathrm{C}=$ Colony diameter in control; $\mathrm{T}=$ Colony diameter in treatment.

Field evaluation of fungicides: Field experiments were conducted at Crop Research Center, G.B. Pant University of Agriculture and Technology, Pantnagar (Uttarakhand). Each field experiment carried out twice in Kharif seasons of 2008 and 2009. Susceptible rice cultivar BPT 5204 was used. General agronomic practices were followed for cultivation of experimental plots. Foliar sprays with fungicides $(2 \mathrm{ml} /$ litre systemic and $2 \mathrm{gm}$ non-systemic fungicides) were given after first appearance of symptoms on inoculated plant tillers. The plots sprayed with tap water served as check. Data was recorded as percent disease severity on artificially inoculated (average 100 tillers/plot) at booting stage. After harvesting yield components (number of filled and unfilled grains per plants, yield per plant and yield per plot), 1000 grainweight and chaffiness were recorded.

Disease severity: Inoculum of S. oryzae was prepared on half cooked rice grains under lab conditions. The colonized rice grains inserted at booting stage of rice plants with the help of forceps in the experimental plots. Individual selected plants were tagged. Inoculated plots regularly observed to first appearance of sheath rot symptoms. Observations on the per cent disease severity on infected panicles were recorded on 15 inoculated tillers after 5 days interval using standard evaluation system rice (IRRI, 1996) rating scale.The rating scale is described in Table 1.

The numerical values were further used for the calculation of PDI (Percent disease index) using the formula:

$$
\mathrm{PDI}=\frac{\text { Sum of individual rating }}{\text { No. of leaves examined }} \times \frac{100}{\text { Maximum disease rating }}
$$

For statistical analysis PDI was converted to angular transformed value.

Effect on yield/plant/plot, 1000-grains weight and chaffiness: Each plot was harvested separately, threshed with the help of a plot thresher. Moisture content of the grains was determined with the help of a universal grain moisture meter. The grains yield was recorded at 14 per cent moisture after 4-5 days of sundrying of the rice grains. On the basis of grain yield from net area of each plot, yield/ha was calculated. One thousands grains weight was obtained by weighting 1000 filled grains obtained from 5 observational plants from each plot separately. Twenty five randomly selected plants from each treatment were harvested and thoroughly threshed with manually, for calculating yield per plant and yield per plots. Chaffiness was calculated by subtracting unfilled grain from total grains produced in the infected tillers for each treatment. The yield data was analyzed statistically.

Screening of rice cultivars/ger mplasm against sheath rot of rice: The experiment was conducted at Crop Research Center, Pantnagar, rice hybrid varietal demonstration trial under field conditions during Kharif season 2009. Hybrid rice varieties were screened against sheath rot severity. Planting of varieties/entries was done on July 27. There were thirty three entries. Each test entry was transplanted in 10 rows of 5 meters row length. Observations on disease severity were recorded at mature flag leaf sheath on randomly selected 15 plant tillers by using 0-9 rating scale given by standard estimation system IRRI (1996). Percent disease index (PDI) was calculated on the basis rating scale and 
varietal reactions observed, are given below:

\begin{tabular}{cc}
\hline $\begin{array}{c}\text { Percent disease } \\
\text { index (PDI) }\end{array}$ & Varietal \\
& reaction (VR) \\
\hline $0 \%$ & Immune \\
$1-10 \%$ & Resistant \\
$11-25 \%$ & Moderately resistant \\
$25-50 \%$ & Moderately susceptible \\
$50-75 \%$ & Susceptible \\
$76-100 \%$ & Highly susceptible \\
\hline
\end{tabular}

Statistical analysis: Statistical analysis of laboratory and field experiments the data was done at the computer centre of G. B. Pant University of Agriculture and Technology, Pantnagar, using appropriate programme as per the requirement of the experiment. The critical difference $(\mathrm{CD})$ was calculated at 5\% level of significance for comparison of difference between the treatments means. Suitable graphical illustrations of data are given at appropriate places.

\section{RESULTS AND DISCUSSION}

In-vitro evaluation of fungicides: The disease symptoms were observed as grayish brown lesions with dark brown margin on the upper most sheaths at booting to heading stage of the rice crop. It observed that lesions on the Table 1. Standard evaluation system rice rating scale. sheath of all the panicles were more frequent and conspicuous on the flag leaf-sheath. In severe infection, entire sheath was covered by several irregular, darkchocolate brown lesions and the panicle was completely chocked or partially depending on the stage of infection. It was also observed that the pathogen also causes sterility in rice plants from sterile florets and discoloure. Systemic fungicides viz., hexaconazole, carendazim, tebuconazole and propiconazole were screened against S. oryzae for their antifungal activity. Maximum inhibition of radial growth $(76.53 \%)$ was recorded at $10.0 \mathrm{ppm}$ of tebuconazole fungicide. Carbendazim was next in order of effectively against $\mathrm{S}$. oryzae isolate inhibiting the radial growth of 64.95\% (Fig. 1). Dodan et al., (1996) reported the efficacy of carbendazim, propiconazole, mancozeb, edifenphos and tricyclazole in controlling sheath rot caused by S. oryzae. Chinnaswamy et al., (1981) found that Bavistin (carbendazim) was the most effective, followed by HMP MBC (carbendazim), Aureofungin and Difolatan (captafol) inhibiting the radial growth of S. oryzae. Reddy et al. (1983) reported that Bavistin was most inhibitory to $S$. oryzae followed by Blue copper and Antracol. Among non-systemic fungicides viz., sulphur, mancozeb, copper hydoxide and chlorothalonil were screened against $\mathrm{S}$. oryzae. Maximum inhibition of radial growth $(78.86 \%)$ was recorded at $200.0 \mathrm{ppm}$ with

\begin{tabular}{ll}
\hline Scale grade & Description \\
\hline 0 & $\begin{array}{l}\text { No lesion/spot on flag leaf sheath. } \\
\text { Spots visible on the tillers upon very careful examination (<1\% flag leaf sheath area } \\
\text { covered). } \\
\text { Spots visible on the tillers upon careful examination (1-5\% flag leaf sheath area } \\
\text { covered). }\end{array}$ \\
5 & $\begin{array}{l}\text { Spots easily visible on the tillers (6-25\% flag leaf sheath area covered). } \\
\text { Spots present on almost whole the tillers parts (26-50\% flag leaf sheath area covered) } \\
\text { damage conspicuous. } \\
\text { Spots very common on whole the tillers parts (51-100\% flag leaf sheath area covered), } \\
\text { death of plants common, damage directly reduce severe yield loss. }\end{array}$ \\
\hline
\end{tabular}

Table 2. Sheath rot incidence on rice cultivars/germplasm of tarai region, Uttarakhand.

\begin{tabular}{|c|c|c|}
\hline S. No. & Varietal reaction & Varieties/entries \\
\hline 1. & Immune & Type-3 and Basmati-370 \\
\hline 2. & Resistance & $\begin{array}{l}\text { Pant Dhan-10, Pant Sankar Dhan-1, Pant Sankar Dhan-3, UP RTGH-332, Pusa } \\
\text { Sugandh-6, Pusa Basmati-1, Pusa Sugandh-5, Pusa Sugandh-4, Super Basmati, } \\
\text { Basmati-386, Tarovari Basmati, Sugandhani, VL Dhan-159, VL Dhan-209, } \\
\text { VL Dhan-85, VL Dhan-82, Pant Dhan-16, Pant Dhan-11 and Pant Dhan-6 }\end{array}$ \\
\hline 3. & Moderate Resistance & $\begin{array}{l}\text { Pusa-44, Narendra-359, Jaya, Pant Dhan-4, Pant Dhan-18, Pant Dhan-19, Pant } \\
\text { Dhan-12, Pusa RH-10, Improved Pusa Basmati-1, Pusa Sugandh-15, Pusa } \\
\text { Sugandh-17 and Pusa Sugandh Dhan-17 }\end{array}$ \\
\hline 4. & Susceptible & - \\
\hline 5. & Highly susceptible & - \\
\hline
\end{tabular}




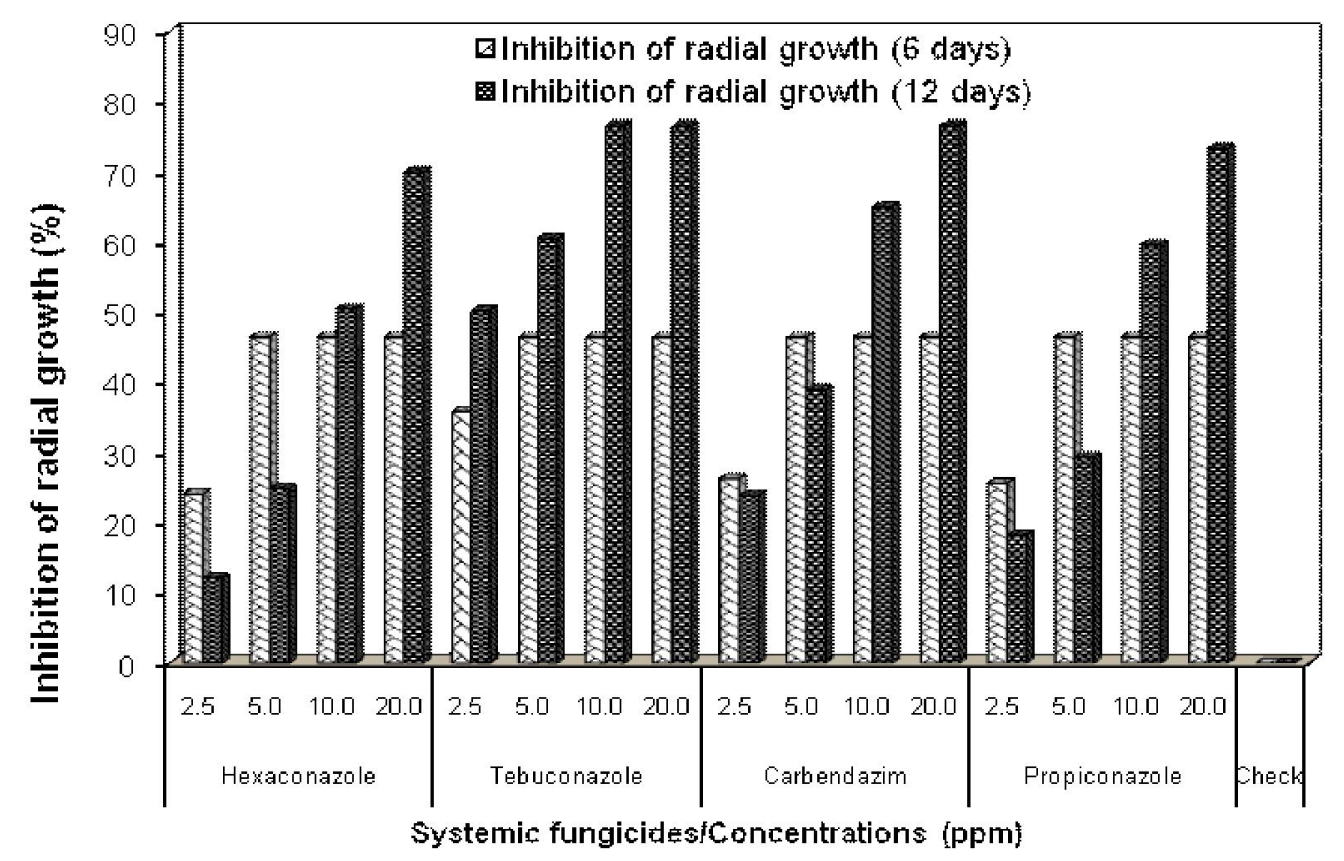

Fig. 1. Efficacy of differ ent concentrations of systemic fungicides on reduction of radial growth of S. oryzae.

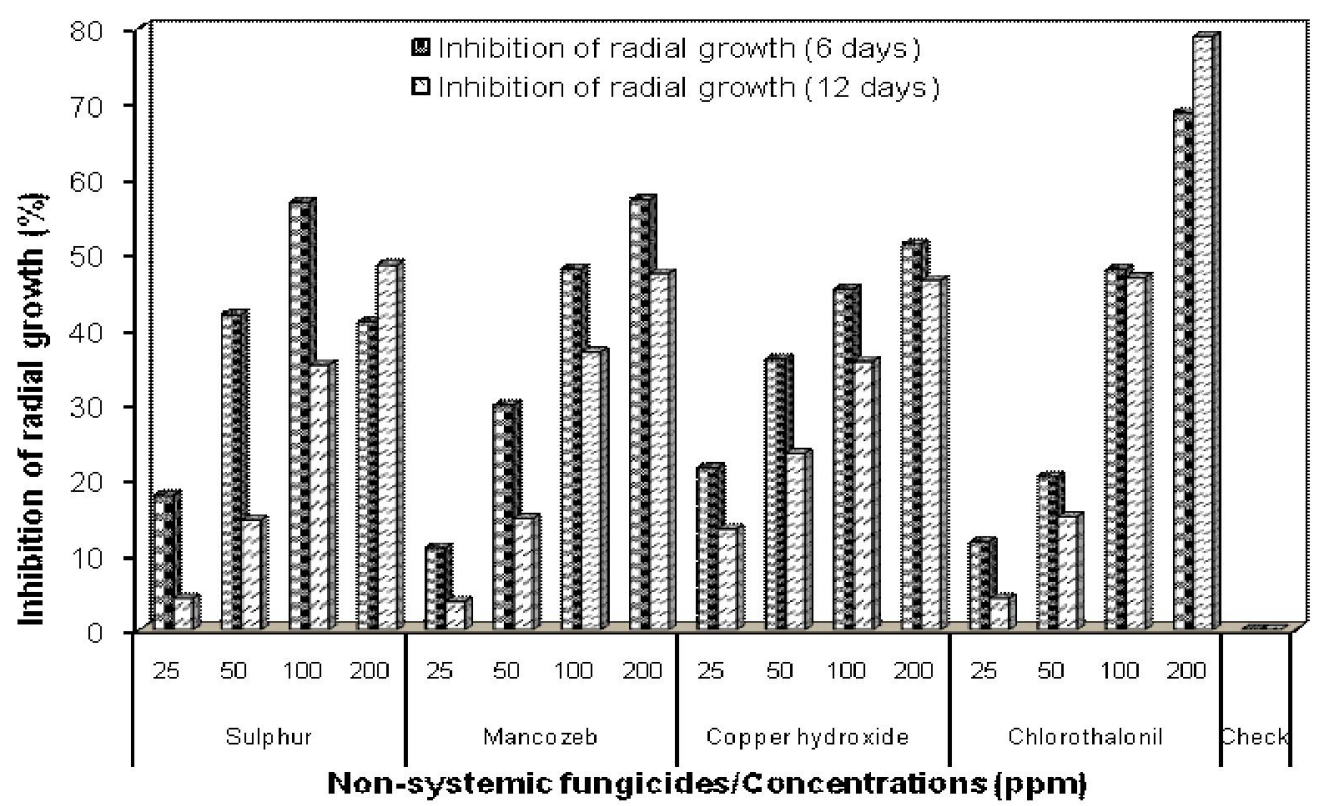

Fig. 2. Efficacy of differ ent concentrations of non-systemic fungicides on reduction of radial growth of $S$. oryzae.

chlorothalonil fungicide (Fig. 2). Sulphur was next in order of effectivity against $\mathrm{S}$. oryzae isolates by inhibiting radial growth of $48.45 \%$. Bolla et al. (2004) also reported the efficacy of six systemic fungicides (edifenphos, propiconazole, iprobenfos, hexaconazole, benomyl and carbendazim) and six non-systemic fungicides (mancozeb, chlorothalonil, ziram, copper oxychloride, methoxyethylmercuric chloride and captafol) and three antibiotics (aureofungin, streptomycin sulfate and kasugamycin) were evaluated in vitro using the poisoned food technique and in field experiments conducted during kharif 2001 at Navsari.
Field evaluation of fungicides: The results indicated that the foliar spray of tebuconazole was superior to other treatments giving reduction in disease severity, which was followed by carbendazim. In the year 2009, maximum increase in grain yield/plant $(45.06 \%)$, grain yield/plot (45.57\%), 1000-grains weight $(10.80 \%)$ and reduction in chaffiness $(53.80 \%)$ were recorded with tebuconazole (Fig. 3 ). The treatment, carbendazim was next in order of effectivity giving $41.46 \%$ increase in grain yield/plant, $41.37 \%$ increase in grain yield/plot, $6.28 \%$ increase in 1000 -grains weight and reduction in chaffiness $(49.59 \%)$. There was minimum increase in grain yield/plant $(8.35 \%)$, 


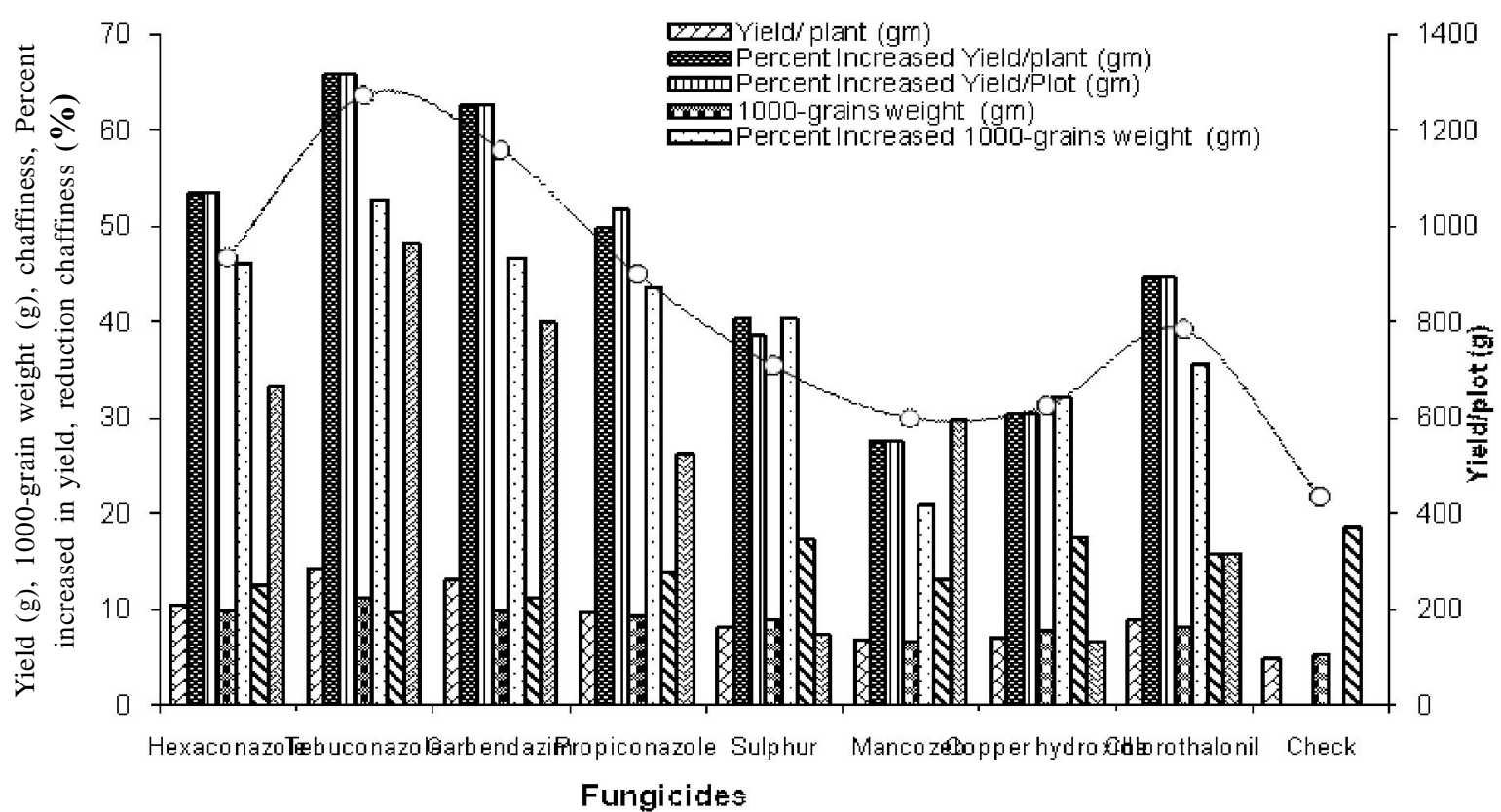

Fig. 3. Comparative efficacy of fungicides on grain yield, 1000 grain wt. and chaffiness under field conditions, applied as foliar spray during kharif 2008.

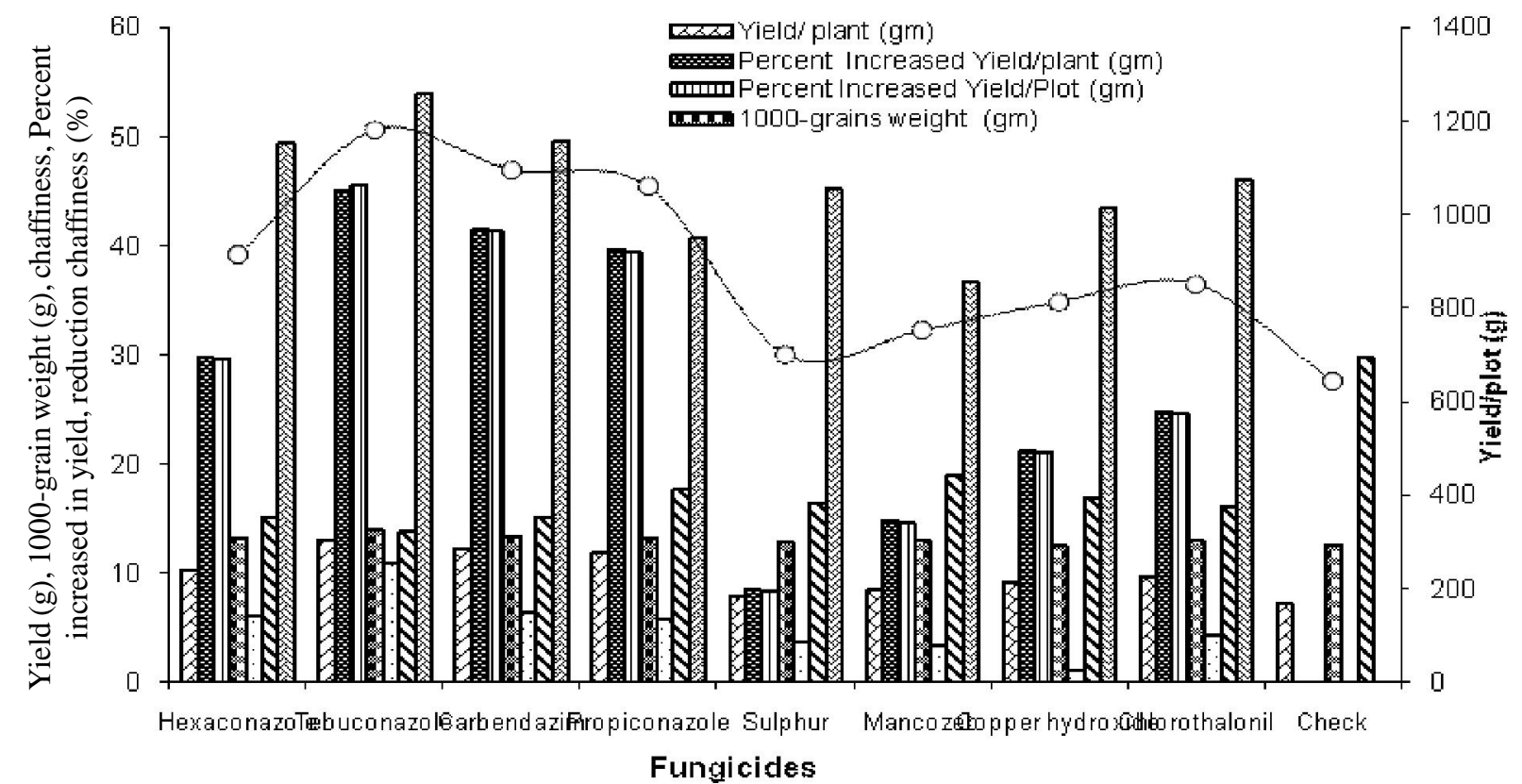

Fig. 4. Comparative efficacy of fungicides on grain yield, 1000 grain wt. and chaffiness under field conditions, applied as foliar spray during kharif 2009.

grain yield/plot $(8.20 \%)$ with sulphur and minimum 1000 grains weight $(0.95 \%)$ with copper hydroxide (Fig. 4). Minimum reduction in chaffiness was recorded with mancozeb (36.64\%). Singh and Raju (1981), Thrimurty (1986) and Karmakar (1992) also reported the efficacy of carbendazim (bavistin) in reducing severity and present findings confirms these reports. Among non-systemic fungicides, chorothalonil was found best in managing sheath rot, giving reduction in disease severity which was closely followed by sulphur and copper oxychloride. Lewin and Vidhyasekaran (1987) reported, all the highyielding cultivars of rice grown in Tamil Nadu are susceptible to Sarocladium oryzae. Several fungicides inhibited growth of the fungus in vitro but none was effective in field trials. Chlorothalonil with Mancozeb, gave the best control.

Natural incidence of S. oryzae: Thirty-three cultivars/ entries were screened against sheath rot under natural conditions. The severity of sheath rot was recorded on selected infected tillers. The PDI was calculated and varietal reaction was observed. Out of thirty three varieties screened against sheath rot only two entries, Type- 3 and Basmati-370 were categorized as immune (Table 2). Chen and Chien (1964) indicated that indica 
varieties were slightly more susceptible to sheath rot than japonica rice. Amin et al. (1974) observed sheath rot on dwarf and local tall varieties. They postulated that the dwarf varieties appeared to be more prone to sheath rot because of their shortened internodes and poor exsertion of the panicle from the flag leaf sheath. Most of varieties (Pant Dhan-10, Pant Sankar Dhan-1, Pant Sankar Dhan-3, UP RTGH-332, Pusa Sugandh-6, Pusa Basmati-1, Pusa Sugandh-5, Pusa Sugandh-4, Super Basmati, Basmati386, Tarovari Basmati, Sugandhani, VL Dhan-159, VL Dhan-209, VL Dhan-85, VLDhan-82, Pant Dhan-16, Pant Dhan-11 and Pant Dhan-6) gave resistant reaction. Sheath rot was more prevalent on high yielding varieties and to a lesser extant on local tall varieties in farmers' fields. However, the cultivars IR 24, IR 26 and Jaya have been reported resistant to sheath rot (Naik, 1976). Remaining entries were designated as moderately resistant. Nevertheless, none of the variety in the present study was recorded as moderately susceptible, susceptible and highly susceptible. Subramanian and Ramakrishnan (1975) assessed some of the newly released and improved varieties of rice to sheath rot under field conditions and observed Sigadis, Kanto, Tellahamsa, TKM 6 and TN-1 as resistant. Chung (1975) observed slight to moderate incidence of sheath rot on indica varieties, IR lines and IR varieties, while all the recommended japonica varieties were disease free. The resistant varieties/genotypes can be used in breeding programme for sheath rot management.

\section{Conclusion}

It was concluded that until the resistance and high yielding cultivars are evolved, it is considered imperative that the rice disease, sheath rot of rice caused by Sarocladium oryzae (Sawada) should be kept under control with minimum possible loss through effective chemical control measure. So, reliance only on fungicides and search for more effective new rice cultivars/ germplasm for the management of sheath rot disease has to be continued, which would help in finding the stable and effective management strategy in the country.

\section{ACK NOW LEDGEMENTS}

The authors are thankful to Head of Department of Plant Pathology and Dean Post Graduate Studies, G.B. Pant University of Agriculture \& Technology, Pantnagar (U.S. Nagar), Uttarakhand for providing necessary facilities.

\section{REFERENCES}

Amin, K.S., Sharma, B.D. and Das, C.R. (1974). Occurance in India of sheath rot of rice caused by Acrocylindium. Plant Dis. Reptr., 58 : 358-360.

Bolla, Venkateswarlu, Venkteswarlu, D. and Chauhan, H.L. (2004). Evaluation of rice genotypes and fungicides against sheath rot of rice caused by Sarocladium oryzae Sawada. J Res. ANG RAU, 32(4) : 59-67.

Chen, C. C. and Chein, C. C. (1964). Some observations on the outbreak of rice sheath rot disease. J. Taiwan Agric. Res., 13: $39-45$.

Chinnaswamy, R., Nair, M. C. and Menon, M. R. (1981). Comparative efficacy of certain fungicides in the control of sheath rot of rice. Agricultural Research J ournal of K erala. 19 (2): $86-88$

Chung, H. S. (1975). Studies on sheath rot of rice caused by Acrocyliandrium oryzae Sawada testing varietal reaction and culture filtrates of the caused fungus. Kor ean J. PI. Prot., 14 : 23-27.

Dodan, D. S., Singh, R., Sunder, S. and Singh, R. (1996). Efficacy of fungi toxicants against sheath rot of rice. Indian J ournal of Mycology and Plant Pathology. 26 (3) : 283284.

Grover, R. K. and Moore, J. D. (1966). Toximetric studies of fungicides against brown rot organisms Sclerotinia fructicola and Sclerotinia lexa. Phytopathology. 52: 876-880.

IRRI (1996). International Rice Research Institute (IRRI). Annual report of rice. Page - 25.

Karmakar, S. K. (1992). Response of rice cultivars against sheath rot disease caused by Sarocladium oryzae (Sawada), W. Gams and D. Hawks Worth, under protected and unprotected conditions. Orissa J . Agric. Res., 5:209214.

Kulwanth, S. and Mathur S.B. (1992). Further evidence of transmission of Sarocladium oryzae through rice seeds and its quarantine significance. Indian Phytopathology. 45(1): 454-456.

Lewin, H.D. and Vidhyasekaran, P. (1987). Controlling sheath $\operatorname{rot}(\mathrm{ShR})$ in rice. Int. Rice Res. Newsl., 12(1):17.

Mckinney, H. H. (1923). Influence of soil temperature and moisture on infection wheat seedling by $\mathrm{H}$ alminthospor ium sativum. J . Agric. Res., 26: 195 - 210.

Mew, T.W., and Gonzales (2002). A Handbook of Rice Seed Borne Fungi. IRRI Science Publishers, pp. 83.

Naik, R. (1976). Incidence of sheath rot in rice- a potential problem in Sambalpur, Orissa. IRRI News L etter. 1: 19.

Reddy, M. M., Reddy, C. S. and Gopal, S. B. (2000). Effect of sheath rot disease on quality characters of rice grain. J . M yc. Plant Pathol., 30 (1): 68-72.

Reddy, E. J. S., Chary, M. P. and Reddy, S. M. (1983). Evaluation of different fungicides in the control of sheath rot of rice caused by Acrocylindrium oryzae. Indian J. M ycol. Plant Pathol., 13(1): 105.

Sachan, I.P. and Agarwal, V.K. (1995). Seed discolouration of rice: location of inoculum and influence on nutritional value. Indian Phytopathology. 48 (1):14-20.

Singh, R.A. and Raju, C.A. (1981). Studies on sheath rot on rice. Int. Rice Res. Newsl., 6(2):11.

Subramanian, C. L. and Ramakrihnan, G. (1975). Varietal reactions to the sheath rot of rice, Acrocylindrium oryzae Sawada Curr. Sci., 6: 151-166.

Thrimurty, V.S. (1986). Studies on chemical control of sheath rot of rice. Pesticides.9: 20-21.

Vidhyasekaran, P., Ranganathan, K. and Rajamanickam (1984). Quality of rice grains from sheath rot affected plant. International Rice Research N ewsletter. 9(5): 5. 